\title{
Secularity as Sacrifice. \\ Notes on the Dialectical Logic in Modernity and its Monotheistic Prefigurations
}

\author{
Laurens ten Kate
}

In religious studies, sacrifice is usually considered as a type of rituality. In this article, to this approach a cultural-philosophical investigation is added. Can sacrifice be analyzed as a general logic underlying Western culture? The author proposes to analyze dialectics as a "movement" typical of Western self-understanding, rooted in sacrifice. Next to examples from Judaism and Christianity, Hegel's secular phenomenology of human life will be the focus here. In dialogue with Jean-Luc Nancy, the consequences of this analysis will be developed. If dialectics is sacrificial, secular modernity is connected in an intricate way with the monotheistic legacy: secularization starts well before modernity. Western history has brought about a transformation of sacrifice in which it is no longer confined within religious practice, but expanded to human "secular" life.

Laurens ten Kate is Associate Professor of Philosophy of religion, Religious studies, Theology and Political ethics, and Endowed Professor of Liberal Religion and Humanism at the University of Humanistic Studies, Utrecht (UvH).

\section{Spectres}

"A spectre is haunting..." Marx's famous opening phrase in the Communist Manifesto has been repeated endlessly in many variations ever since. Where the Manifesto ascribes the presumed spectral force and threat to nineteenth century communism in Europe, numerous philosophers, scientists, writers, journalists and artists have followed Marx's dictum while re-identifying the spectre. Lately, Peter Sloterdijk has opened his book Du mußt dein Leben ändern with a description of the "spectre of religion" and of its claimed "return" that would haunt the western world in the $21^{\text {st }}$ century. ${ }^{1}$ In the economic and political sciences one has encountered several spectres "haunting America", either in a leftist-progressive or in a rightist-neoliberal disguise. ${ }^{2}$ Even in contemporary music the phrase proves

1 Sloterdijk 2009, p. 9.

2 See e.g. Stone's influential study "A Spectre is Haunting America: An Interpretation of Progressivism"; and more recently Mogan 2009, who warns the then new president Obama of "ghosts of neoliberalism" that would undermine the political innovations he'd promised. 
its fascination and attraction: in 2002, a Vancouver post-punk or "death rock" band was formed that changed its name to "A Spectre is Haunting Europe" a few years later, eschewing variations of the spectre and simply going back to the Manifesto's literal opening statement. The most fundamental analytical account of Marx's phrase and of its "spectral" impact in our time has been delivered by Jacques Derrida, in his Specters of Marx. ${ }^{3}$

As a preamble to this article (section 1), I will introduce yet another spectre: the spectre of growth. As I will demonstrate in the analysis succeeding this preamble, the spectre of growth has a lot to do with its Marxist archetype, since it leads us back to the theoretical basis of Marx's political theory: Hegelian dialectics. It is the dialectical movement as a central "subject" - driving force and object matter - of Hegel's thought, that I will articulate as a sacrificial logic (section 2).

But Sloterdijk, maybe inadvertently, is right too: the spectre Marx has set free is at the same time the spectre of religion. For the sacrificial logic active in the dialectical movement in turn leads us back to monotheism and its complex views on and experiences of sacrifice. The monotheistic legacy still active in our time entails a specific transformation of sacrifice: a transformation that is in fact a dialecticization (and from there, a universalization, ethicization and spiritualization) of sacrifice, converging in Hegel's thought (section 3). However, if the spectre of growth is in fact the spectre of dialectical sacrifice, one will have to raise the question whether it is possible to think beyond this spectral logic: beyond dialectics, and maybe even beyond sacrifice. Such an immense question can only be suggested "between the lines" of this article, limited in volume as it needs to be, and in a final coda.

\section{Growth}

Growth and growing appear to be a non-negotiable truth and foundation of modern times. This becomes apparent above all in modern economy and economic thinking, and its system of an ever expanding free market ruled by competition between owners of capital. In this system called, as well all know, capitalism, growth is the equivalent of the never ending accumulation of capital, strived for by the owners of this capital. Capital can accumulate itself only when it engenders profit, gain, interest, surplus value: these words, that have crept into modern languages as signifiers everybody immediately can handle and understand, are just a few of the many denominators and indicators of growth. Capital, in other words, is only meaningful when it increases: when it is on the move constantly, making huge profits that enable even huger re-investments, so that it will never stop accumulating. It increases when it launches new technologies for

3 Derrida 1994, esp. Ch. I. 
new products, designs new infrastructures to facilitate the flow of capital by a quick and effective distribution of products, explores new ways of exploiting natural resources and of appropriating the ecological system of the planet for its own purposes - of "de-naturizing nature"; it increases when it conquers and even invents new markets of consumers, and engages new production forces in the shape of new groups of (preferably) cheap laborers. These are some central features of modern capitalism that reflect the massive emphasis on the logic of "crescendo" inherent to the economic thinking of modernity.

Once national, European and, ultimately, global economies do not grow anymore, one speaks of a recession, and soon of a crisis. Maybe this is what Marx wanted to address when he described capitalism as a political economy: it is based on the political decision (self-evident, almost unconscious) that economic life be a life of endless growth. Strangely, the political movement opposing and challenging capitalism since Marx's time, socialism or communism, is even more indebted to this truth and foundation of growth. Its belief in a history of progress leading to an "ideal state" is critical of capitalism's unjust distribution of evergrowing wealth, but it does not criticize the foundation itself; on the contrary, in the end, all of humanity should benefit from growth. The crises in a world based on the fevers and growing pains of capitalism, first in the nineteen thirties of the previous century, then in the eighties and at present in our new century in the form of a bank and monetary crisis, may have puzzled the believers in capitalist and socialist doctrine, the idea that growth and expansion is a compulsory dynamics of modern life has remained intact even so. This economic principle rules from right to left, and dominates the unstable societies we are living in, that profit from capitalism and are being jeopardized by it at the same time. Since the implosion of communist totalitarianism in the last decades, there appears to be no alternative to the whims and caprices of capitalist growth - and it is doubtful that communism has ever been an alternative to it in the first place. The voices of those who at least warn against an ecological disaster caused by growth, still remain weak, the gestures of those who decide to "occupy" parts of the western world's cities for no other reason than to raise a simple question: why growth?, still remain vulnerable and uncertain - and hence are easily laughed away.

Consequently, the growth principle governs not only the economy, but all of our societies, all of our lives. It governs working life first and foremost: once someone does no longer "grow" in his career, he is judged to become marginal in the organization in which he is employed, then he is labelled superfluous, and ultimately denounced as a failure. In many European languages one finds a variation of this English saying - that is among the most heard in the fields of economy, trade and work: "Standstill is decline".

Growth and its parallels, expansion, dynamics, improvement or scoring, seems to be the sign of the time - of the way modern people work in the world and of the way they view the world. The world, our world - that is, the world that is our property and playground for growing - , is above all a process. Also when one does 
not work, one likes to grow, to be on the move toward what one is not now. One "grows" in one's relationships, as it is said, or one "grows" as a person. Most of the now popular ethics of life style and of the "art of living" is dependent on this logic. One has to work on oneself, improve oneself, and this is usually conceptualized as a search for one's truth and authenticity - one's better self -, a search that should never stop: only in this way we become more self-controlled, determinate, "mindful". To mention one further example, modern holidays, too, are processes in which one likes to explore new countries and cultures, enriching oneself while absorbing new impressions. "Expanding borders", for instance, is one of the key metaphors in the language of present day commercials.

But why is the idea of growth such a strong idea? Because - and here I return to the hypothesis formulated in the opening - since the beginning of western history, and in particular since the rise of modernity, it has taken a complex form: the form of a dialectical dynamics, based not on growth itself but on sacrifice. Let us now explore the possibilities of this hypothesis.

\section{Dialectical Growth - the Secular Sacrifice}

\subsection{Classical Dialectics: The Method}

In western Antiquity, in the Middle Ages, but also, for instance, in Indian philosophy dialectics indicates a specific kind of philosophical reasoning through dialogue. In the dialogue, of which those of Socrates are the most famous, both partners depend on one another; personal views and convictions must be risked, tested and reformulated in the process of the exchange with the other, so that between the two the truth will emerge. In this sense, dialectical dialogue is different from classical debate (in which the debaters hold on as long as they can to their opinions, trying to convince the other of the correctness of these opinions and "winning" the contest in this way) and from classical rhetoric (in which a speaker attempts to persuade an audience to follow his opinion, using the instruments of attraction and seduction through eloquence). In a dialectical exchange the partners need to temporarily give up their knowledge, insights and views, in order to obtain something new and better from the exchange, from the encounter with the other. ${ }^{4}$ Already here, in the old practices of dialectics, we encounter a certain sacrificial logic, albeit only at the level of reasoning and its

4 Needless to say, Socrates's dialogues are not just famous, but also quite ambiguous examples of this encounter. One may equally well defend the position that Plato presents Socrates as the omniscient director and manager of the dialogues, dominating them with smart anticipation and manipulation of his fellow debaters, and hence not taking part at all. 
procedure: dialectic dialogue is fundamentally relational and reciprocal, and hence it always involves some loss of the self.

\subsection{Modern Dialectics: Hegel's Innovation: Dancing around the Negative}

In modernity this relational approach to reason and to its critical potential has been deepened out by many thinkers. Let me just mention one of them: Kant, as a brief stepping stone to our main area of questioning, that of Hegel's work.

Kant's concept of "pure reason" indicates a reason that relates with reality, manipulating it and being manipulated by it - this is a continuous process, and as a consequence (1) no reason can ever claim to be ultimately "pure", but must develop a sense ${ }^{5}$ of its finitude; (2) dialectical reasoning is no longer aimed at the establishment of truth, but at the discovery of the inaccessibility of truth: the processes of our reasoning are always exceeded, transcended by the Ding an sich one cannot properly "know".

However, after Kant's innovations in the use of dialectics as a relation between subject and object, that generates a sense of the finitude of this relation, it is in Hegel's work that dialectics is finally and explicitly broadened to a universal and all-encompassing logic. It is no longer limited to (a specific way of) reasoning, nor to epistemology, but becomes an ontological and existential term. Dialectics is the way history proceeds, and it is the way humans live their existence in that history. In Hegel's phenomenological project, dialectics winds up being more than a method: it is a fundamental feature of being itself. One goes from methodology to ontology here. This Hegelian ontology is, needless to say, not a classical metaphysical theory of being as substance or essence, but it is radically relational: in this sense Hegel builds on Kant and in fact on the entire tradition of dialectical dialogue. But the relation is applied to existence, to life itself; that is the first new element here.

What type of relation are we dealing with, then? What is new in Hegel's system of dialectical life? Of course, this relation is not simply a function of two preexistent subjects - or of a subject and an object - that temporarily form a relation with one another, as if the relation were their product, the result of their intentional act. The relation itself becomes important, as an event between two subjects and not as their function. But again, this is not new in Hegel: as we saw above, dialectical dialogue has always concentrated on a "truth" "happening" between the partners. New in Hegel's approach to dialectics is not the between and the event itself, but the way he fills this event with a new meaning: that of negativity or,

5 Throughout his three Critiques, Kant uses sometimes sensus, sometimes Anschauung or Erfahrung (often translated as intuition and as experience), sometimes Einbildung to address and articulate various aspects of this sense of the finitude, that is, of the limits of human reason. 
in a less conceptual and more fluid formulation, of the negative. That is the second new element here. It is in this negative center of the dialectical relation that one finds sacrifice in its modern, secular form.

\subsubsection{The Self and the Negative}

Hegel views this relation as one of the self and the other. The self (subject, identity, ego, to name some of its signifiers) can never rest in itself and coincide with itself: it has to be on the move - it has to grow. In order to develop itself and "realize" itself, as Hegel calls it, the self has to move away from itself, risk, leave, lose, alienate itself. More precisely, it has to give itself away to the other: to whom or what is strange to me and does not coincide with my identity. Meanwhile, the other does likewise, giving up his self reciprocally. The formal terminology for this movement is the famous triad thesis - antithesis - synthesis, that Hegel himself never used, ${ }^{6}$ but that summarizes and simplifies Hegel's own theory of negation and sublation: the self (thesis) can only become "presence to self" by negating itself (antithesis), and, through that mediating negation, sublate (aufheben) itself (synthesis). The negative moment as the confronting encounter with the other is the axis around which turns the entire dynamics: it always comes back to the negative. After all, the self is nothing else than this negative moment: it can only be "itself" in the negation of self, and is nothing "in itself". This self-on-the-move, this self without selfness, Hegel calls "spirit". The negative this spirit exposes itself to, this negative as and with the other (the negative is in a way the other, and it is the event to which the self abandons itself together with the other who does likewise) is often described by Hegel in terms of death and dying, as well as of the endurance of this death: in other words, it is described in terms of sacrifice. Death and destruction appear here as moments that are of the greatest importance for life and construction. The dialectical movement, as Hegel thinks it, is a sacrificial movement on a fundamental level. It temporarily enacts death as a vital element of the life of the self, and it does so in a ritual way: the enactment has to be repeated time and again, since it forms, as we saw above, the basic ontological structure of life and history.

But the life of Spirit is not the life that shrinks from death and keeps itself untouched by devastation, but rather the life that endures it and maintains itself in it. It wins its truth only when, in utter dismemberment, it finds itself. It is this power, not as something positive which closes its eye to the negative, as when we say of something that it is nothing or false, and then, having done with it, turn away and pass on to something else; on the contrary, Spirit is this power only by looking the negative in the face, and tarrying with it. This tarrying with the negative is the magical power that converts it into being. ${ }^{7}$

6 It was Fichte who developed this triadic structure, and later it was used by Heinrich M. Chalybäus in order to explain Hegel's philosophy.

7 Hegel 1977, § 32, p. 19. 
In this passage, Hegel's language - maybe inadvertently - is embedded in the vocabulary of sacrifice. The negative event defining the Spirit has "magical power" (earlier in this section he speaks of the "tremendous power of the negative"), and actually this event is a "conversion", a transformative gesture characteristic of many forms of sacrificial rituals. More importantly, "Spirit" is defined here as this death-enacting, sacrificial self, that lives its life in a continuous movement of negation and sublation.

\subsubsection{The Sublated Self and the Negative}

But let us not pinpoint and fixate Hegel's idea too easily here: the sublated self is not simply some goal achieved, a final point of the dialectical unrest. Hegel thinks the sublated self, the "other", higher, elevated, "grown" self, in terms of pure becoming, or infinite finitude: it is still a movement, not the fullfilment of a movement; and it refers back to the central event of negation. Sublation "is" nothing, it is simply and radically: becoming. The sublated self detaches itself from immediate selfhood, it "loosens itself" (ab-solvere) from any self-being, and in this way becomes "absolute", as Hegel states. The absolute is not what it looks like, and partakes in the negative moment instead of overcoming it. It is not life after death, but life in death. The "living Substance", Hegel formulates in his typically enigmatic and concentrated style, "is actual [one can also say: realized, or sublated - LtK] only in the movement [...] of the mediation of its self-othering with itself. This Substance is, as subject, pure, simple negativity..." Again we see that the "living substance" Hegel refers to here (a substance that is no classic substans at all, since it "lives" and hence is pure becoming) can only keep on "dancing" around the negative, mediating between different positions. In fact it is this negative, enveloped as it is in its own dance. In other words, this "living substance" is the Spirit of sacrifice that holds the entire structure of the dialectical system together.

\subsection{Modern Growth and its Success: From Linearity to Dialectics}

If Hegel is right in extending dialectics to individual and collective life itself, then consequently that typically modern feature we earlier designated as growth is more complex than it seems. It is not a simple, natural, linear process toward a given end, but it is an ambivalent movement in which interruption or interception are the basic categories: what is can only grow by risking everything, including itself. There is no straightforward "walking the line" from $a$ to $b$, where the walker - the self - would remain intact. Reaching for $b$ - the other - involves the disintegration of $a$ and of its walking action: the line must be interrupted, broken, in order to be successful. Modern growth is dialectical: it is a question of losing and

8 Ibid., $\$ 18$, p. 10. 
finding oneself, of humiliation and elevation, of sacrifice, and gain through sacrifice. One grows by sacrificing oneself - one grows by not growing. Increase and decrease become dialectically entangled here.

Moreover, dialectical growth turns out to be a very active gesture, instead of being a linear process that has its own automatic movement and that befalls the self, like in the growth of a juvenile body toward adulthood. On the contrary, modern man has to do a lot in order to grow, whether this be of the order of the accumulation of his possessions or of the improvement and elevation of his personality and existence. He has to invest what he has, what he is, expose himself to the uncertainties and risks of the secular sacrifice analyzed by Hegel as the event of negation, and finally, through these challenges, he manages to grow. It is this active structure of dialectics that renders the modern preoccupation with growth so successful. Sacrifice develops into something one does to and with oneself: it fills the abyss opened by secularization (the death of God), by recreating a form of sacrifice that does no longer need gods to sacrifice to. In the dialectical movement circulating around the negative moment, sacrifice becomes a gift to oneself through a gift of oneself. We will have to return to this fundamental cohesion between western, modern sacrifice and self-sacrifice later on. ${ }^{9}$

9 Hegel thinks this continuous circulation of the self around its moment of negation as the definition of self-consciousness, esp. in Part IV of Phenomenology of Spirit. After having identified dialectics as negative moment in $\S 204$, in $\S 205$ he then describes the dynamics of self-conciousness as an "absolute dialectical unrest". The self that takes his "self" as its primary object, its "reality" to be "realized" through sacrifice, is never "itself", never "self-identical", but consists in its "own" "process", its "own" movement (of negation, sublation, of lost-and-found), that is, its "own" unrest of which it is fully aware. But it is just in this process that this consciousness, instead of being self-identical, is in fact nothing but a purely casual, confused medley, the dizziness of a perpetually selfengendered disorder. It is itself aware of this; for it maintains and creates this restless confusion. (Hegel 1977, § 205, p. 124 f.) Later, in 1830, Hegel applies this concept of unrest to the spirit itself: "Spirit is not an inert being, but on the contrary, absolutely restless...”. See Hegel 1971, § 378, p. 3. See on the notion of dialectical unrest also Nancy 2002. Nancy connects the unrest of the self with that of the world - of the way sense emerges and recedes in the world, as an infinitly finite event. "This world is therefore not a simple result, nor does it have a result. It is the world itself that results in its own movement, and the thought of its own truth is itself, in turn, a movement and a restlessness - the very same, in fact, to the extent that it is restlessness of self, for itself, and uneasy about itself; and because it reveals itself as other, infinitely in the other." (Ibid., p. 6) 


\subsection{Growth and Crisis: The Economy of Sacrifice}

Let us return briefly to our opening analyses. The examples of what we have called the "spectre of growth" all follow the dialectical logic clarified above. This spectre is modern precisely because it is a sacrificial spectre. That is most and for all apparent in the way capitalist economy creates its own crises, and ultimately war as the temporary, radical destruction of capital. ${ }^{10}$ Investing money - with different degrees of risk - in order to make profit with it is the daily dialectical pattern of capitalism, a pattern raised to a highly speculative and spectacular level in the stock markets. But the crises in this hectic system should not be interpreted as temporary flaws and drawbacks in the system: they belong to its structure of negation and sacrifice. Marx was quick to observe this, for example in his Theories of Surplus Value: "Crisis is no contingency but a certainty"; and "The crisis is the manifestation of all the contradictions of bourgeois economy". ${ }^{11}$ These contradictions Marx analyzes here in discussion with David Ricardo are the contra-

10 Among the abundant literature on the relation between capitalism and war I just mention a more recent study, that offers an informative overview of the debate as well as a first historical analysis of the new civil and ethnic wars following the downfall of the Soviet empire, and the 'wars on terror' occupying American foreign politics after 9/11: Nitzan / Bichler 2004, pp. 255-327. That war would be an integral element of the free market system refers to a broader approach to war, in philosophical and historical research, exploring war as a form of sacrifice, as a sudden outburst of the negative event, in which a collective, a nation gives itself away in excess and ecstasy in order to assert itself anew. In this violent sacrifice one would meet the religious and esthetic 'reservoirs' of modern rational culture. Seen this way, modern war appears as the most intense and radical moment of the dialectical movement, as its ultimate expression. This hypothesis is treated in an equally abundant amount of literature. I just mention Georges Bataille's work on the "experience" of war as a void within culture, leaning in particular on Nietzsche's critique of modern rationality and instrumentality. Bataille concentrates his explorations on the Second World War and on the understanding of modern fascism. With regard to the First World War there is Modris Eksteins's amazing study Rites of Spring: The Great War and the Birth of the Modern Age; Eksteins analyzes the growing desire for a great sacrifice in French, German and English culture in the fin de siècle: "The war, ironically, was a matter of life, not death; it was an affirmation of vitality, energy, virtue. The war was a matter of art," he paraphrases Hermann Hesse (94). In order to demonstrate the cohesion of art and warfare, of the radically new directions taken in music, theatre, painting etc. and the interruptive 'freshness' of war, Eksteins presents Stravinsky's and Diaghilev's ballet "Le sacre du printemps" (1913) as the shocking choreographic and musical announcement of a political event that would exceed the limits of diplomacy: the Great War. The relation between war and sacrifice and its connection with modern dialectics is an important theme within the context of my line of thought here, but I cannot go into it any further now. See also Ten Kate 1994, esp. ch. II.

11 Marx, Theories of Surplus Value (1861-1863), ch. XVII, § 10. 
dictions of dialectics, in that the bourgeois can only effectuate progress and growth by risking it, thereby risking the lives of the "production forces" (the workers) he is dependent on for the accumulation of his capital. As a matter of fact, "the very nature of capital leads to crises", Marx states time and again in this text. ${ }^{12}$ Marx's analysis was provocative in his time, but has not lost any of its actual relevance. Recently, the economist Andrew Kliman has convincingly deconstructed the crises in the American economy, and its global consequences, by demonstrating how the "destruction of capital" is a vital force in the economy. ${ }^{13}$ Kliman is only one of many scholars pointing at this paradox. We will have to conclude that the sacrificial logic underlying modern growth is far from an innocent rituality "also" belonging to modern history; quite to the contrary, being its driving force, it may set the scene for a destruction beyond control and without return of this world.

We have seen how Hegel, leaning on Kant's preparatory investigations, introduces a new concept of dialectics touching upon a logic of sacrifice. Hegel claims that this concept may elucidate modernity and its unique history, and uncover its prime driving force. In doing so, however, Hegel does not only look into the future; he rephrases a dialectical dynamics hiding within western culture since its beginning. The religions of the West: the three monotheisms, and particularly Christianity, have contributed to a great extent to the imagination, ritualization and examination of this dynamics. In this sense, the "spirit" articulated in the conceptual framework of dialectical phenomenology, the spirit of modern life, leads us back in many ways to the "Spirit of Christianity" and its "Fate" that Hegel already investigates in his early works. ${ }^{14}$ Let us explore elements of this legacy in the following section.

12 Ibid., opening statement of the chapter, and passim. A few years later, in Capital, Marx refines this by giving a merciless reconstruction of the development of the English cotton industry between 1830-1860, showing how this has produced an excess of alternating crises and booms (some no longer than one year) only to end up being the most flourishing and wealth generating English industry towards $1860 \ldots$ In 1863 the entire cotton production definitely collapses. It is this immense inconsistency and inefficacy, this relentless destruction at the cost of countless exploited lives, as well as the class resistance against it, that interests Marx. See Marx, Capital, ch. 13, § 7.

13 See Kliman 2007; esp. Id. 2009, pp. 47-54.

14 See Hegel 1996. 


\section{The Secular Sacrifice: Prefigurations in Western History: The Monotheistic Legacy}

If Hegel is first and foremost rephrasing an inheritance, then when in our cultural history did this dialectical preference begin to emerge? And what has happened to sacrifice if it is true that this history, long before Hegel, is to be qualified as dialectical? So far, we have analyzed to what extent dialectics bears a sacrificial kernel in it. Let us turn this question around, and see whether sacrifice has a dialectical kernel since the beginning of the West. In order to do so, I will partly make use of the thought of Nancy in as far as this is relevant for our topic.

\subsection{Nancy and the "Westernization" of Sacrifice}

In his text "The Unsacrificeable" (1990) Nancy develops a historical and philosophical account of the differences between on the one hand pre-western and nonwestern traditions of immolation and sacrifice, and western sacrifice on the other: "What is the nature of the West's initial relation to sacrifice? More precisely: upon what kind of relation to the sacrifices of the rest of humanity [...] does the West map out, so to speak, its 'own' sacrifice?"15

Nancy depicts this differential relation by indicating three features in which western sacrifice distinguishes itself from the long traditions of sacrifice that do not fit into this western logic, or remain at the margin of it: from what Nancy, rather quickly and easily, names "the rest of humanity." ${ }^{16}$ First, western sacrifice is no longer simply bound to specific moments and places: it is happening always and everywhere. Second, western sacrifice loses its exemplary and substitutional character. And third, it distances itself from instrumentality, having no longer any goal than itself and its own gesture.

\subsubsection{Sacrifice Breaking with Time and Place}

From time immemorial sacrificial rites, practices or gestures have been momentary events, dependent on a specific and unique occasion (even though this occasion may repeat itself in a steady pattern, like daily) and usually also on a

\footnotetext{
15 Nancy 2003, pp. 51-77; 54.

16 As if this "rest" has not been penetrated and determined by western culture at least since the latter established itself as "global" or "globalization"; and as if this "rest" has not started penetrating, fascinating, challenging and transforming the West since its beginnings. Sloterdijk, and in different but parallel fashion Nancy, both have, by the way, critically analyzed how and why the history of the "West" and that of globalization coincide in a fundamental way: western culture is the culture of the discovery, the exploration and colonization of the globe - a "coincidence" that has been brought to its peek in modern capitalism. See Sloterdijk 2005, and Nancy 2007.
} 
specially designated place: the altar, the temple, a mountain, the home, the front door... Here, one sacrifices some object(s) or victim in order to achieve something: to avert a curse, to propitiate the gods, to make atonement, to undergo an ordeal, to express gratitude, to ask for a blessing or benediction. Sacrifice is a temporary step outside regular life, and cannot be identified with that life. But this identification is precisely what happens to sacrifice in the West, Nancy observes: "The uniqueness of sacrifice is thus transferred - or dialecticized - from a position of exemplary uniqueness, whose value lies in its exemplarity [...], to the uniqueness of the life and of the substance in which - or to which - every singularity is sacrificed." 17

Nancy shows how especially in Christianity this transfer has taken place, for instance in Paul's criticism of pagan sacrifice as against Christ's sacrificial life to be worshipped and imitated by the Christians, or in Augustine's view on sacrifice: the entire "City" of believers is constantly offered to God in one universal sacrifice, or: the soul itself should become a sacrifice when it offers itself to God. ${ }^{18}$ Here sacrifice detaches itself from its concrete occasion, and becomes the infinite gift of self to the other: God. This dialectical life, Nancy summarizes in Hegelian terms, "is, in and for itself, nothing other than sacrifice." ${ }^{19}$ Not amazingly, Nancy states that at the end of this western-Christian process of a certain infinitization of sacrifice, "we find Hegel". ${ }^{20}$

\subsubsection{Sacrifice Breaking with Exemplarity: The Triumph of Self-sacrifice}

But if sacrifice is a life, and not a special event interrupting life, what is left to be sacrificed? In the sacrificial traditions the West is breaking away from, the sacrificed is almost always a substitute for the sacrifier. This substitute, often the animal, but in some ancient cultures, like the Aztec civilization, also a human being, is the exemplary figure representing those who perform the sacrificial practice. The substitute is literally an exemplum, from the Latin verb eximere meaning "to take out". It is taken out of the religious community in order to represent that community, and likewise the individual belonging to that community, who takes the decision to make a sacrifice, is represented by the sacrificed being. So the self of the one who sacrifies is not completely irrelevant; it is relevant within the event of the immolation in as far as it is exemplified by the victim. Through the exemplification the self touches upon its negation carefully, with respect and awe, but never absorbs this negativity.

This absorption is, however, characteristic of western sacrifice. Here, every sacrifice primarily becomes self-sacrifice, from Augustine, who exhorts us to

17 Nancy 2003, p. 57.

18 See the Epistle to the Hebrews 10:11-14, and Augustine: The City of God, Book X-6: "Of the True and Perfect Sacrifice."

19 Nancy 2003, p. 56.

20 Ibid., p. 57. 
present our bodies as a "living sacrifice" ${ }^{21}$, to Hegel's phenomenology revealing this structure of self-sacrifice in a secular and systematic manner. In such a dialecticization sacrifier and sacrificed become entangled, if not entirely synonymous. In this rupture with exemplarity and substitution, one meets the most important feature of westernized sacrifice, according to Nancy. He offers two examples, one from Antiquity, one from Christianity. First he mentions Socrates's death (a sacrifice not to the gods, but to truth and reason and in this sense, the first major tale of a self-sacrifice), then God's incarnation in Christ. He thinks this incarnation, later articulated by Paul as kenosis, ${ }^{22}$ as the becoming radically human of God, that is, of a sacrifice of God as God into humanity, so that of Godas-God nothing remains. The central figure of worship is transformed from divinity to human mortal flesh (caro, hence incarnation). It is Christ who is divine only as human.

Then, doubling this sacrifice of God in the narrative and subsequent doctrine of incarnation that has become the central trope of discussion and fascination throughout Christianity's history, the story of the gospels unfolds in such a way that the paradoxical divinity of this human being, of Christ consists in his being slaughtered. The sacrifice of God into humanity doubles itself in a sacrifice of humanity that, in this sacrifice, finds its divinity, that is, its being "not of this world" while being "in the world". ${ }^{23}$ "[...] Becoming man even unto death, God, lord and master over the death of all creatures, inflicts his death upon himself, returning to himself and his glory the life and love he has lavished upon creation. ${ }^{24}$ Or in a more rude, harsh language, Bataille, whom we will pay attention to in a while, adopts the same approach to the coincidence of the incarnational sacrifice and human life as sacrifice: "God is dead. He's so dead, in fact, that the only way to make this comprehensible is by killing myself." ${ }^{25}$

Elsewhere Bataille addresses the sacrificial mode of existence as a limit-point, rather than as a transgression of limits. Self-sacrifice has little to do with a heroic decision to enter death, but it is a hesitant, even aporetic lingering on the limit of life: Hegel's negation as an "endurance" of the moment between life and death, treated above. Only this limit-point is humanity's - is Christ's - "divinity": "God is not humanity's limit-point, though humanity's limit-point is divine. Or put it this way - humanity is divine when experiencing limits." ${ }^{26}$

In view of our analysis of the dialectic movement as a form of existential sacrifice, thoroughly dependent on Christian ethics and antropology (Hegel was

\footnotetext{
21 Augustine: The City of God, Book X-6.

22 See e.g. the famous passage in Philippians 2:7.

23 See John 18, where the author tackles this complex structure of inside-outside through Jesus's words.

24 Nancy 2003, p. 56.

25 Bataille 1988, p. 85.

26 Ibid., p. 105.
} 
very keen to admit this inheritance, as we saw above), I think Nancy has good grounds to analyze the incarnation as an imitable sacrifice. Whereas traditional theology holds that Christ has sacrificed himself once, only to expel sacrifice from the world and thus prevent humans to sacrifice one another, a more challenging reading of the incarnational narratives would conclude that with Christ's death on the cross, sacrifice has become the prime model for Christian life. Self-sacrifice as a way of life is intensely present in all three monotheisms, but only in the Christian arche-narrative of the Gospels this self-sacrifice has been evoked in a literal and physical way: the death of God on the Cross, endlessly remembered and repeated, even imitated in the traditions of eucharistic rituality. Considered in this sense, the eucharist is less a ritual in which humanity is repeatedly redeemed from its sins through Christ's "once and for all" sacrificial mediation - resembling a traditional, pagan cleansing ritual -, but a ritual in which humanity is repeatedly exhorted to double Christ's sacrifice - Christ's death - in their daily lives. Christ and his sacrifice are always with and among us, but this presence, this parousia leads to nothing. It has no higher goal than... sacrifice itself.

Let me refine and clarify this rather unorthodox conclusion by following Nancy's argument, adding my comments and excursions to it.

\subsubsection{Sacrifice Becoming Ethical}

What interests us here is the ethical transformation of sacrifice: much more than a religious act expressing the relation with gods, it becomes a life style. I "do" sacrifice, I "am" sacrifice, I lead my life in a sacrificial (and following from the centrality of this "I": self-sacrificial) mode. I will test myself rather than let myself be tested by God. The traces of this crypto-humanistic, ethical reduction of sacrifice can be found in the views on man and on the world - in the anthropology and cosmology - of the Cynics and the Stoics in Antiquity, and their successors in Christian asceticism: here abandonment, moderation and limitation (being in accord, "in measure" with the cosmos by giving up selfhood and self-indulgence) are the indicators of the sacrificial logic, leading to the idea of a detached, "free", higher self that is actually selfless. The so-called "ethical religions" (the three monotheisms) feed strongly on these ethical reshapings of sacrifice in the Roman world of the last centuries B. C.

\subsubsection{Spiritualized and Universalized Sacrifice}

Similarly, next to its being "ethicized", western sacrifice is rendered spiritual and universal above all: it is no longer concerned with a real offering, with slaughtering a victim, but, by extending sacrifice to ethical life, it shifts the focus on the spirit of sacrifice. It "mimes" traditional, physical sacrifice on a spiritualized level, Nancy writes, then quoting Pascal's famous words: "Circumcision of the heart, true fast, 
true sacrifice, true temple: the prophets showed that all this must be spiritual. Not the flesh that perishes, but the flesh that does not perish."27

Reflecting on this passage, Nancy goes as far as to state that the "truth of sacrifice" is that it dialecticizes itself literally: it "sublates, along with "the flesh that perishes', the sacrificial moment of sacrifice itself." ${ }^{28}$ Exactly in this sublation, sacrifice becomes universal: it is there every time and everywhere, and no longer needs the particularity of temporality and locality.

Against this background, it is strange and almost cynical to have to conclude that despite the West's spiritualization of sacrifice, its history has produced probably the most cruel and bloody slaughter of all humanity. The question whether the de-ritualization of sacrifice, its liberation out of its ritual confinements in favor of a spiritual sacrifice, would has unleashed violence on a totally different scale, needs to remain unanswered in this context. But posing and treating this question is all the more urgent in our time. One of the more lucid thinkers of the twentieth century, Georges Bataille has attempted to pose and elaborate this question in 1943, against the background of the atrocities of the Second World War. He paves the way for an understanding of what universal sacrifice might imply face to face with the "total war" fascism desired to absorb human life into. Here one meets a thinker who has gone thoroughly through Hegelian dialectics, who recognizes how right Hegel is in his articulation of modern life, and who still does not agree, by no means. Bataille reverts to his other teacher, Nietzsche, to show how and why secular sacrifice and its dance around the negative is far from being a innocent progression in the history of humanity. What does universal sacrificial logic look like? What if it culminates finally into a practice, into a politics? The task will then be - and Bataille, in 1943, felt confronted with it - to think a "sacrifice in which everything is victim". ${ }^{29}$ Then he cites Nietzsche, who in Beyond Good and Evil (1885) describes a historic "ladder of religious cruelty", proceeding from pre-western to medieval to modern sacrificial traditions, including the dialectical variety:

Finally - what remained to be sacrificed? At long last, did one not have to sacrifice for once whatever is comforting, holy, healing; all hope, all faith in hidden harmony, in future blisses and justices? Didn't one have to sacrifice God himself and, from cruelty against oneself, worship the stone, stupidity, gravity, fate, the Nothing? To sacrifice God for Nothing - this paradoxical mystery of the final cruelty was reserved for the generation that is now coming up: all of us know already something of this. ${ }^{30}$

27 Nancy 2003, p. 58. The citation is from Pascal 1966, p. 109.

28 Ibid.

29 Bataille 1995, 130-157.

30 Bataille cites Friedrich Nietzsche, Beyond Good and Evil, fragment 55. Translation by Leslie Anne Boldt, translator of Inner Experience. 
However, this is only one side of Bataille's rethinking of sacrifice in the twentieth century. The political criticism of sacrifice, as Bataille already diagnosed this in the "Psychological Structure of Fascism" ${ }^{31}$ is a very complex criticism, for it entails an affirmative diagnosis at the same time. For Bataille the political extremities of his time mirrored a type of sacrifice that in his view can only by comprehended if one affirms that it is a key feature of modern, and indeed Western existence. In e.g. modern eroticism and ecstacy, the orgies are a secular transformation of archaic, pagan rituals of sacrifice, he states in his 1956 study Eroticism ${ }^{32}$. This secularization of sacrifice has been prepared by Christianity, he claims, since Christianity has rejected the sacred character of erotic sacrifice by rendering it a profane act. In eroticism "we" are all still Christians, and the flip side of this provocation is true too: Christianity persists in secular modernity, not as a religion proper: an institution, a church, but as eroticism and its irrational abandonment.

How? According to Bataille's train of thought, Christianity as well as modern eroticism (either in its literal, "real" shape, or in its evocations in art and literature, in the "violence of poetry" ${ }^{33}$ ) both follow the structure of sacrifice as self-sacrifice - as negation. This is why Bataille, despite his fierce criticism of Hegel's phenomenological system, could easily observe that "Hegel, c'est l'évidence." And this observation is also a sigh: "Often Hegel seems obvious, but this obviousness is hard to put up with." 34

\subsubsection{Secularized Sacrifice}

Let me revert to Nancy's genealogy of sacrifice. Finally, having become spiritualized and universalized, sacrifice opens the possibility of its secularization. As a life style, why would it need a God, a holy book, a religious doctrine, ritual traditions? This secularization of sacrifice is not at all only a modern phenomenon, though we have seen above how radically it is interwoven with modern dialectical growth. One meets this secularization already in Augustine. In the Confessions the dialectical movement between man and God, between the confessing "I" giving everything away (indeed, confession is surely a form of selfsacrifice too) and its Other, is dominated in a remarkable way by the human side of the relation. "I" offer myself to God, but this God's meaning or role is primarily to give the "I" back to itself: so the "I" be sublated, that is, purified, enriched. This movement between man and God has to be repeated and renewed continuously, as we have seen, so that the negative, sacrificial moment is kept in the centre and

\footnotetext{
31 Bataille 1979, pp. 64-87.

32 Id. 2012.

33 See Bataille 1976, pp. 187-189. In this little radio speech, Bataille places the experience of sacrifice at the heart of his theory of the relation between the sacred and the secular.
}

34 Litt.: "Hegel is the obvious." Bataille 1988, p. 105. 
kept alive; but the Other in the relation is first of all a function of the self. The believer's spirituality is concentrated not on worshipping transcendent power, but on the discovery of one's own "truth", one's authenticity, as I showed above. Needless to say, Augustine still puts a lot of effort in saving and preserving this transcendence, but the "highest God" the author of the Confessions evokes, is only meaningful as the "interior God": the God-in-me. Mark the central place of the meo (me, mine) in this well-known dictum: "Interior intimo meo et superior summo meo." God is "more inward to me than the most inward part of me; and higher than my highest height." God is $m y$ inward and $m y$ height. ${ }^{35}$

It is not difficult to see how such a dialectical logic applied to the relation with God already announces modern dialectics. Individualism has not been invented by the modern era, but by early Christianity and one of its protagonists, Augustine. The "other" as God will, in modernity, be transformed into the human other, and then ultimately into the other self, "my" other self: the secularization and humanization of self-sacrifice. But the ingredients for this transformation were already active in the Confessions.

\subsubsection{Sacrifice Breaking with Instrumentality}

The meaning of this self-sacrificial movement analyzed so far reveals itself in a particular sense in Judaism. One only has to think of the strong exodic and nomadic exigency in the Thora. The people of Israel may not settle and rest in and within its "self", its identity, but it can only experience its "self" as destination, that is by wandering in the desert, by being in exile, by being dispersed. God's people can only be God's if it loses itself continuously, and persists in waiting for salvation, for a "promised land", for the Messiah. This self-sacrificial wandering and waiting is what counts. The Jew must "dance around the negative": there lies the mystery of his religion. Pursuing this approach to Judaism's preoccupation with leaving and roaming, with deserting oneself and one's home in order to enter the homelessness of the desert where Jahwe can be met, one may need to say that Abraham's famous sacrifice (Gen. 22) of his son Isaac is not where his sacrificial life started. In the offering of the son Abraham is asked by God to give up everything, that is, to sacrifice the unthinkable; here it is still a test, ending well when God changes his plan and reverts to traditional substitutional sacrifice: Abraham is allowed to sacrifice a ram instead. But already in the first verse of Genesis 12, a crucial chapter opening the so-called Abrahamic narrative that will structure the rest of the book Genesis, Abraham - then still named Abram - is summoned to leave behind everything he has and start his nomadic journey. It is

35 Augustine: Confessions, Book III, vi (11). My translation; summo meo is often translated as "my highest reach" or the like, but this is an incorrect neutralization of the remarkable formulation: Augustine draws a parallel between "my inward" and "my height", almost as if attempting to describe not God, but the divinization through sacrificial confession of man: it is all "mine". 
here that God requests Abram he abandon his "self", stop being who he is, and show he does not cling to anything contributing to his identity: "Now the Lord said to Abram, 'Go forth from your country, and from your relatives, and from your father's house, to the land which I will show you..."36

Here one encounters most emphatically the third feature of westernized sacrifice Nancy mentions, that of a rupture with instrumentality. The sacrifice of exodus toward desert life has no other goal than wandering; the "promised land" is not a straightforward goal to be reached after desert life; it is a promise parallel to the messianic expectation of the prophets, maybe - that moves on with the wandering journey, so that in the end one does not know whether the desert is the promised land after all. Whenever the people arrives somewhere to settle, it must go on. And whenever it defies this logic and does settle after all, things go wrong and a new exile is due. Here, at the dawn of western history, in the stories of Tenach that, later, also have obtained their central place in Christianity, one is confronted already with the restless self, affirming itself as a constantly moving and "growing" being, or rather, as dynamic and infinite growth itself. It always comes back to its negation, to the negative moment we studied above when we dealt with the spectre of modern growth and its Hegelian complexities. Western sacrifice is self-referential, it looks for its own gift time and again: it is this gift caught up in the looping spiral of lost-and-found.

\subsubsection{Death in Life, Life in Death}

With regard to Islam, the self-sacrificial rigor of monotheism is advocated even more strongly, almost obsessively in the Koranic rhetoric suggestion that life and death are closely involved into one another - a rhetoric strategy that is quite dominant throughout the sura's: "[...] you were without life and [Allah] gave you life. He will cause you to die and again bring you to life [...].".37 Here it is God himself who regulates the sacrificial structure of human existence, without engaging himself in that life, as the Christian God does in the incarnational narrative and doctrine.

This is just one example of the way in which monotheism transposes death, and more significantly, the act of dying, towards life itself, the eternity and infinity of its "still waters" towards finite time: outside becomes inside without giving up its outside character. Monotheism invents and installs an art of living, a life style and a form of spirituality (often expressed in ascetic exercises and rituals) in which man experiences his existence, as Nancy explains in another text, "as a life withdrawn from time in the very course of time." This amounts to a new interpretation of the idea of eternal life - so influential in Islam from its beginning, and in Christianity from its middle, medieval period - as well, since eternal life is now situated within finite, mortal life as its other:

36 Gen. 12:1 (New American Standard Edition).

37 Sura 2:28. Maulana M. Ali Edition. 
[...] Eternal life is not life indefinitely prolonged, but life withdrawn from time in the very course of time. Whereas the life of ancient mankind was a life measured by its time, and the life of other cultures was a life in constant relation to the life of the dead, Christian life lives, in time, what is outside time. ${ }^{38}$

The believer always, "eternally", and in a fundamental way, falls short of himself, undergoes his life as unfulfilled. One has to step outside of oneself, die temporarily, give oneself away to the Other, in order to regain oneself anew, and in an enriched, purified way. That is the logic of conversion that stamps the monotheistic religions and the way they shape our life practices. They have, in other words, prepared and prefigured us to the dynamic frenzies of dialectic sacrifice.

Examples of this are quite well-known and numerous. In the Judeo-Christian tradition, one only has to look at the key rituals and parables that have determined this religion for two millennia: one always finds this dynamic of dying in order to live, culminating in dying as a form of living. I mention baptism by immersion (a ritual of drowning temporarily and of cleaning/purifying); confession as a way of abandoning oneself by avowing one's secrets and sins to the other, the priest, as we saw this in Augustine's Confessions; the emphasis in Tenach, analyzed above, on exile and erring, and on the desert as a place of displacement and wandering that at the same time is the place of the revelation of the Thora - the desert as a space where the people loses itself only to meet its God in this lost position; the rhetorics in Christianity that parallels this Jewish call to wander and stay faithful to the desert, like in the parable of the "prodigal son" (in some languages more correctly entitled the "lost son"), who comes home after having given everything away (was it really just wasting what he had done?) and hears his father say: "[...] This son of mine was dead, and he has come to life again." 39

But one can also find the voices articulating this new complexity between life and death outside the immediate legacy of monotheism: for example in the "technologies of the self" developed by the Stoa as these are analyzed philosophically by Foucault, ${ }^{40}$ in medieval radical mysticism as this is rephrased by in

38 Nancy, "In the Midst of the World, or: Why Deconstruct Christianity?", Preamble to Alexandrova / Devisch / Ten Kate / van Rooden (eds.) 2012, p. 2.

39 See Luke 15:24 (New American Standard Edition). The parabolic suggestion is obvious (according to the majority of exegetic interpretation nowadays) in this famous story told by Jesus in response to the Pharisees' question "Who are you?": this so-called prodigal son refers to the Son (Christ speaking in masked terms about himself), the father in the parable is God the father.

40 See Michel Foucault in Martin / Gutman / Hutton 1988, pp. 16-49; this seminar took place in October 1982. Foucault demonstrates in the homonymous text, "Technologies of the Self", to what extent Stoic ethics has determined early Christianity, e. g. in the taking over and reformulation of practices of confession (exomologèsis and exagoreusis). Foucault bases himself in this genealogic determination of Christian culture on Pierre Hadot's investigations. The Greek-Roman world cannot simply be opposed to 
Bataille's philosophical and literary work, in Heidegger's existential analysis of Dasein as sein zum Tode (being toward death), or in Levinas's exposure of the "I" in the ethical rapport to the other, the neighbour, in whom God appears to me in order to give me back to myself as a self who is "otherwise than being, beyond essence". ${ }^{41}$

\section{Coda: Beyond Sacrifice?}

Why growth? Why is it so self-evident and virtually non-negotiable? And why has dialectics, at least in the complexities of western history, been the format for growth? So that growing eventually obeys to a logic of sacrifice? We have treated these questions in this article, that is about to end now in an inevitable coda, launching a further question: why do we need growth? Is a world, a history, a life thinkable beyond growth?

A first possibility of an answer to these questions lies in the attempt to rehabilitate and "re-imagine" sacrifice, as Kathryn Mc Clymond does in her Beyond Sacred Violence. She criticizes the "western reduction" of sacrifice, draws attention for non-western sacrifice, for example in Hindu religious traditions, and claims that a non-essentialistic, pluralistic or "polythetic" approach to sacrifice as a "dynamic matrix of activity" can open our eyes to forms of sacrifice that would reach out "beyond violence". ${ }^{42}$ But is western sacrifice a reduction, or rather a mimetic radicalization of traditional sacrifice? Is it physical violence, or spiritual? And how close is dialectical life to McClymond's "matrix of activities" that would show how sacrificial gestures are a part of daily existence rather than belonging to the realm of well-defined rituals?

Nancy looks into a second, different direction, not one of a certain re-evaluation of sacrifice, but one of "the effacement of sacrifice, of communion, of the West", as he calls it towards the end of "The Unsacrificeable". Here, the attention is drawn to the unsacrificeable character of existence, and of the sense of that existence. "Existence [...] can't be sacrificed. It can only be destroyed or shared." ${ }^{43}$ For Nancy, the sharing (partage: a key concept in his entire work) of existence and of its continuously emerging, "happening", that is, finite sense, "would efface the sacrificial mimicry of an appropriation of the Other". ${ }^{44}$ Sharing

monotheism, but has to be deconstructed alongside the monotheistic religions as their building material. Both are figurations of the logos breaking away slowly from mythos and in this sense they are "laboratories" of new research on the relation between death and life.

41 See Levinas 1991.

42 See McClymond 2008, ch. 1, "Re-imagining Sacrifice”, esp. p. 27.

43 Nancy 2003, p. 77 (also previous quotation).

44 Ibid. 
is presented here as a relation between the self and the other that undermines the dialectical relation on a fundamental level: that undermines the realization of the self through the other in the event of negation. In this way, the concept of the "self" is itself being undermined: sharing decenters the subject. Sharing, thought here as an almost ontological condition of existence, decenters the subject, because this subject is no longer the center of the world and of life in that world: losing its superiority, its primordiality with regard to the world (as in a subjectobject relation), the subject can no longer give sense to the world - a giving that would imply it can also destroy the world if it wishes. The "self" can no longer "travel" the world, conquer and appropriate it (by negating and then reaffirming it, as in the dialectical movement), it can only be "exposed" to the world and share its sense. The world does not have sense, it is sense; the "self" does not give sense, but it shares sense with and in the world, that is, with the other. Such a sharing gesture differs radically from any sacrificial dialectic: one does not share by offering, by abandoning (for instance natural resources or nature in general, wealth and goods, or life itself: my own life or the other's), but by receiving. This sharing builds no communal experience, no community proper; but it exposes us to relations, dependencies, passions, networks we do not master - it exposes us to the world we are.

Not appropriating the other means breaking away from sacrifice, according to Nancy. To share would then mean giving up the idea that any relation to the other, to the world has to follow the logic of investment and exchange: two of the pillars of modern economy. Sharing beyond sacrifice would suggest one goes from investment to gift: where there is abundance of capital ${ }^{45}$, why is it self-evident that this abundance must be reinvested in order to grow? Why can it not "simply" be spent, given away, de-appropriate itself? Is an economy of the gift thinkable? As a further example of the condition of sharing, one may think of the other as the world in its biophysical form: the strive for "sustainability" in our relation to the world appears to oppose the modern logic of sacrificing the world in order to transform it into an "other" we can use and "exploit".

However, dialectics is not synonymous with appropriation, as we have seen above when concentrating on the negative moment in the dialectical movement: the spirit as Hegel thinks it, is by no means an exclusively appropriating force, but a self-on-the-move, without selfness, a self-as-other. Nancy will surely agree that the relation between self and other - this relational "spirit", this spirit-as-relation Hegel devotes his project to - bears elements of the sharing of and "in" the sense he himself is looking for. Precisely because the spirit entails a restless and finite dynamics, in which neither the self nor the other let themselves be appropriated fixed, identified, realized -, it may well already open the realm of partage. But

45 And of wealth for a very small privileged group around the globe; if we may once again rely on Marx's analyses, an economic crisis does not at all mean there is less abundance, on the contrary... 
then sharing and sacrifice do no longer oppose one another, but rather are mutually contaminating and even inspiring concepts.

As a consequence, it is necessary to explore a third way to answer the question of this coda. We may have to look for the "beyond" in dialectics, rephrasing it instead of trying to overcome it. Is Bataille right in stating that dialectics, in the end, refuses any logic of growth, precisely because of what dialectics is and has always been: a "dance around the negative", installing the infinity of negation in the heart of our lives and relations? What could be the potential of Bataille's idea that in the dialectical loop nothing is constituted but a négativité sans emploi that problematizes the system from the inside? ${ }^{46}$ This is, according to Bataille, a negativity that leads nowhere but to the threshold of excess, where we are called to pull up between selfhood and loss of self. Here, dialectical sacrifice is "read against the grain", or against itself from within: a deconstructive approach undertaken by many critical philosophical responses to Hegel in the last half century. ${ }^{47}$ The kernel of all these deconstructions is the attempt to rid dialectics of the phantasm of growth.

But let me leave the issue of a "beyond" unanswered for the time being, inviting further research on this in the near future. ${ }^{48}$ Let me end into the open, then, and stay faithful to the infinity of the coda. ${ }^{49}$ The urgency of this issue merits such

46 The formulation of a négativité sans emploi (idle, useless, litt. "unemployed" negativity) is used by Bataille in a letter to Alexandre Kojève dated 6 december 1937. See Bataille 1973, pp. 369-371.

47 As in Blanchot's and Derrida's work, or in that of Nancy, as far as The Restlessness of the Negative is concerned; in "The Unsacrificeable", as we have seen, he tends to be more critical of the dialectical logic proper, eventually aiming at a refutation of it. See in this perspective also Malabou 2005. Malabou rethinks the dialectical movement of the spirit towards its Aufhebung as a gesture of plasticity: the spirit does not realize and elevate itself, but it rather "fashions" itself (like a plastic artist, a sculptor e. g., fashions his stone material) continuously - a process, an "act" that follows, according to Malabou, the structure of "simplification" and surrender to "habit" instead of a structure of amplification and growth (p. 152). In the "plastic operation" (p. 145) the spirit "reduces its own resistance, becomes more supple, flexible, malleable [...]", and in this way "an alienation we could call sacrificial" is "elicited [from] spirit". The dialectical schema boils down, Malabou states, to this self-fashioning and -refashioning of the spirit, in which it renders itself "plastic", that is, it "distances itself from itself", and "sheds its own self", in a "self-sacrifice" that is at the same time its "survival", its future life and potentiality. See p. 152 for all citations. Here, dialectics is rethought by distancing it from growth but not from sacrifice. Indeed, the plastic gesture is dialectics' beyond right within dialectics. 48 This invitation is, in a way, already being accepted, and serves as a driving force behind current work in progress, leading to my book on humanism and Christianity, in progress.

49 "Coda" literally means the tail of a body: not a finale or conclusion, but a part 
future research, for the schema Hegel still put his faith into, however complex and nuanced his train of thought has been, may well be exhausted and have become self-destructive in the $21^{\text {st }}$ century. A difficult shift will impose itself in the coming decades, a shift in our views on economy, on life style, on our relation with nature and with the globe, and on the plurality of intercultural, complex and hybrid identities in a globalizing world.

\section{References}

Augustine: Confession. Book III.

Id.: The City of God. Book X.

Bataille, Georges: Eroticism. London 2012.

Id.: Guilty.Translation by Bruce Boone. Venice 1988.

Id.: Inner Experience. New York 1995.

Id.: "Le sacré au vingtième siècle", in: Oeuvres complètes VIII. Paris 1976.

Id.: Oeuvres complètes, vol. V. Paris 1973.

Id.: "The Psychological Structure of Fascism" translated by Carl R. Lovitt, in: New German Critique (16) 1979 [1933], pp. 64-87.

Derrida, Jacques: Specters of Marx: The State of the Debt, the Work of Mourning, and the New International. London 1994.

Eksteins, Modris: Rites of Spring: The Great War and the Birth of the Modern Age. New York 1990.

Hegel, Georg W. F.: Encyclopedia of Philosophical Sciences, III: "Philosophy of Mind", Wallace edition. London - Oxford 1971.

Id.: Phenomenology of Spirit, Miller-Findley edition. London - Oxford 1977.

Id.: "The Spirit of Christianity and its Fate" (1799), in: Early Theological Writings. Philadelphia 1996.

Kliman, Andrew: Reclaiming Marx's Capital: A Refutation of the Myth of Inconsistency. Lanham 2007.

Id.: "The Destruction of Capital' and the Current Economic Crisis", in: Socialism \& Democracy (23/2) 2009.

Levinas, Emmanuel: Otherwise than Being or beyond Essence. Dordrecht - Norwell 1991.

Malabou, Catherine: The Future of Hegel: Plasticity, Temporality and Dialectic. London - New York 2005.

Martin, Luther H. / Gutman, Huck / Hutton, Patrick H.: Technologies of the Self: A Seminar with Michel Foucault. Amherst 1988.

Marx, Karl: Capital. A Critique of Political Economy. London 1976.

Id.: Theories of Surplus Value (1861-1863). New York 2000.

McClymond, Kathryn: Beyond Sacred Violence: A Comparative Approach to Sacrifice. Baltimore 2008.

coming after that body (e.g. a musical "body": a composition), and at the same time leaving that main body "unfinished" endless, letting it evaporate into open air. 
Mogan, David: “A Spectre is Haunting America”, in: In These Times, $8^{\text {th }}$ of March 2009. Nancy, Jean-Luc: Hegel: The Restlessness of the Negative. Minneapolis - London 2002. Id.: "In the Midst of the World, or: Why Deconstruct Christianity?", Preamble to Alexandrova, Alena / Devisch, Ignaas / Ten Kate, Laurens / Rooden, Aukje van (eds.): Re-treating Religion: Deconstructing Christianity with Jean-Luc Nancy. New York 2012.

Id.: The Creation of the World, or Globalization. New York 2007.

Id.: "The Unsacrificeable", in: A Finite Thinking. Stanford 2003, p. 51-77.

Nitzan, Jonathan / Bichler, Shimshon: "Dominant Capital and the New Wars", in: Journal of World Systems Research (10/2) 2004, pp. 255-327.

Pascal, Blaise: Pensées. Harmondsworth - Middlesex 1966.

Sloterdijk, Peter: Du mußt dein Leben ändern. Frankfurt am Main 2009.

Id.: Im Weltinnenraum des Kapitals. Eine Philosophie der Globalisierung. Frankfurt am Main 2005.

Stone, Alan: "A Spectre is Haunting America: An Interpretation of Progressivism", in: Journal of Libertarian Studies (3) 1979, pp. 239-260.

Ten Kate, Laurens: De lege plaats. Revoltes tegen het instrumentele leven in Batailles atheologie (The Empty Place: Revolts against Instrumentality in Bataille's Atheology). Kampen 1994. 